\title{
Effect of Integrated Nutrient Management on Floral Parameters and Soil Nutrient Status in Chrysanthemum (Chrysanthemum morifolium Ramat.)
}

\author{
Geeta Pandey ${ }^{*}$, Rakesh Kumar, Santosh Kumar and Ajit Kumar
}

Department of Horticulture, College of Agriculture, G.B. Pant University of Agriculture and Technology, Pantnagar, Uttarakhand, India

*Corresponding author

A B S T R A C T

\section{Keywords \\ Chrysanthemum, Vase life, Nutrient, Vermicompost, Azotobacter \\ Article Info \\ Accepted: \\ 16 April 2018 \\ Available Online: \\ 10 May 2018}

Cultivar Prof. Harris performed better in terms of flower diameter $(10.00 \mathrm{~cm})$, fresh and dry weight (57.9 and $15.97 \mathrm{~g}$ ) of cut flower, whereas cultivar Sunil showed longer flower stem length $(48.66 \mathrm{~cm})$, water uptake $(90.78 \mathrm{ml})$ and vase life (20.41 days). Application of $75 \%$ recommended dose of fertilizer and vermicompost coupled with dual inoculation of Azotobacter and VAM proved most effective in enhancing the flower stem length (53.68 $\mathrm{cm})$, more flower diameter $(11.97 \mathrm{~cm})$ and enhanced vase life of flowers (22.70 days). The highest water uptake $(93.51 \mathrm{ml})$ and maximum available nitrogen $(184.23 \mathrm{~kg} / \mathrm{ha})$, phosphorus $(28.53 \mathrm{~kg} / \mathrm{ha})$ and potassium content $(192.26 \mathrm{~kg} / \mathrm{ha})$ was recorded in treatment with application of 75\% RDF + Azotobacter + VAM + vermicompost (T15).

\section{Introduction}

Chrysanthemum (Chrysanthemum morifolium Ramat.), which occupies a prominent place in ornamental horticulture, is one of the commercially exploited flower crops belongs to the family Asteraceae and is known as "Queen of East". It is native to the northern hemisphere and is widely distributed in Europe and Asia. However, it is believed that, its origin is China. The plant grows erect and tall making it suitable for border planting, cut flowers and loose flower for garland making, general decoration, hair adornments and religious function. It is also grown in pots for flower shows. Out of the various factors affecting the growth and flowering of chrysanthemum, balanced nutrition is very important. Chrysanthemum is a heavy feeder of nutrients specially nitrogen and phosphorus (Nalawadi, 1982). At present, these nutrients are supplied through chemical fertilizers. But due to rising cost, indiscriminate and continuous use of chemical fertilizers in intensive cropping system, there is imbalance of nutrients in soil which has an adverse effect on soil health, yield and quality of crop (Sunitha and Hunje, 2010). Therefore, the integrated use of nutrients is the need of hour. Integrated Nutrient Management (INM) concept is one of the eco-friendly approaches. INM is the better option for the improvement of physical, chemical and biological properties of soils (Das et al., 2015). INM holds great 
promise in exhibiting the growing nutrient demands of intensive farming like floriculture and maintaining productivity at its optimum with holistic improvement in the quality of resource base, which is very much important in-case of cut and bulbous flowers (Wani et al., 2017). Hence, an attempt was made to reduce the amount of nitrogenous, phosphatic and potassic fertilizers by substituting with organic manures and biofertilizers (Azotobacter and PSB).

The use of INM in varying combinations was reported to be beneficial for increasing yield and quality of flowers. Hence, the adoption of this practice will be proved advantageous for the farmers. Keeping this in view, the present investigation was undertaken to study the influence of integrated nutrient management on floral parameters of chrysanthemum and nutrient status in the soil.

\section{Materials and Methods}

The present experiment was conducted at Model Floriculture Centre, G.B.P.U.A. \& T., Pantnagar, Uttarakhand during July, 2008 to February, 2010. The treatments consisted of two chrysanthemum cultivars viz., Prof. Harris $\left(\mathrm{C}_{1}\right)$ and Sunil $\left(\mathrm{C}_{2}\right)$, and different combination of inorganic and organic fertilizers viz., control $\left(\mathrm{T}_{1}-100 \%\right.$ Recommended dose of fertilizer- RDF), $\mathrm{T}_{2}-\mathrm{VAM}+$ Azotobacter+ vermicompost; $\mathrm{T}_{3}-75 \% \mathrm{~N}+$ Azotobacter + full dose of $\mathrm{P} \& \mathrm{~K} ; \mathrm{T}_{4}-50 \% \mathrm{~N}+$ Azotobacter + full dose of $\mathrm{P} \& \mathrm{~K} ; \mathrm{T}_{5}-75 \% \mathrm{P}+\mathrm{VAM}+$ full dose of $\mathrm{N} \& \mathrm{~K} ; \mathrm{T}_{6}-50 \% \mathrm{P}+\mathrm{VAM}+$ full dose of $\mathrm{N} \& \mathrm{~K} ; \mathrm{T}_{7}-75 \% \mathrm{RDF}+$ vermicompost; $\mathrm{T}_{8}$ $-50 \% \mathrm{RDF}+$ vermicompost; $\mathrm{T}_{9}-75 \% \mathrm{RDF}+$ Azotobacter + vermicompost; $\mathrm{T}_{10}-50 \% \mathrm{RDF}+$ Azotobacter + vermicompost; $\mathrm{T}_{11}-75 \% \mathrm{RDF}+$ $\mathrm{VAM}+$ vermicompost; $\mathrm{T}_{12}-50 \% \mathrm{RDF}+$ $\mathrm{VAM}+$ Vermicompost; $\mathrm{T}_{13}-75 \% \mathrm{~N}$ and $\mathrm{P}$ + Azotobacter + VAM + full dose of $\mathrm{K} ; \mathrm{T}_{14}{ }^{-}$ $50 \% \mathrm{~N}$ and $\mathrm{P}+$ Azotobacter $+\mathrm{VAM}+$ full dose of $\mathrm{K} ; \mathrm{T}_{15}-75 \% \mathrm{RDF}+$ Azotobacter +
$\mathrm{VAM}+$ vermicompost and $\mathrm{T}_{16}-50 \% \mathrm{RDF}+$ Azotobacter+ VAM + vermicompost. Four week old rooted cutting of chrysanthemum were transplanted at a spacing of $30 \times 40 \mathrm{~cm}$. Nitrogen, phosphorus and potassium (100\%, $75 \%$, and $50 \%$ ) were applied along with vermicompost $(1 \mathrm{~kg} / \mathrm{ha})$, Azotobacter and VAM as per treatment. Azotobacter was applied in the form of slurry by dipping the cuttings for 30 minutes before transplanting. Whereas, VAM @ 2 g/plant was applied at the time of transplanting in the holes made for transplanting the cutting.

The experiment was laid out in Factorial Randomized Block Design (RBD) with three replications. Data on various flowering parameters viz., flower stem length, flower diameter, fresh and dry weight of cut flower, water uptake by cut flower, vase life and available N,P and $\mathrm{K}$ in the soil were recorded and statistically analyzed.

\section{Results and Discussion}

It is evident from the data presented in Table 1 that cultivar Prof. Harris performed better in terms of flower diameter $(10.00 \mathrm{~cm})$, fresh and dry weight (57.9 and $15.97 \mathrm{~g}$ ) of cut flower, whereas cultivar Sunil showed longer flower stem length $(48.66 \mathrm{~cm})$, water uptake $(90.78$ $\mathrm{ml}$ ) and vase life (20.41 days). This might be due to genotypic differences between both the cultivars due to which they respond differently. Further significant influence of different treatment combinations of reduced doses of inorganic fertilizers along with organic fertilizers on various floral parameters and soil nutrient status was observed. The treatment $75 \%$ RDF + Azotobacter + VAM + vermicompost (T15) proved most effective in enhancing the flower stem length $(53.68 \mathrm{~cm})$ followed by T13 $(51.23 \mathrm{~cm})$, T $5(49.96 \mathrm{~cm})$, $\mathrm{T} 11(48.49 \mathrm{~cm})$ and $\mathrm{T} 1(46.36 \mathrm{~cm})$. Whereas, minimum mean stem length $(36.04 \mathrm{~cm})$ was observed in VAM + Azotobacter + 
vermicompost (T2). The enhancement in length of flower stem is also attributed to an increase in level of growth promoting substances particularly gibberellins due to presence of organic fertilizers. Gibberellins accelerate concentrations of hexose sugars (mainly glucose) and acid invertase activity, and increased concentrations of these are the major factors influencing elongation. Similar findings have also been reported by Nandre $e t$ al., (2005) in China aster and Mukesh Kumar (2015) in chrysanthemum.

Flower diameter $(10 \mathrm{~cm})$ of cv. Prof. Harris was more in comparison to cv. Sunil (9.44 $\mathrm{cm})$. Diameter of flower was significantly increased by integrated use of nutrients from different sources as compared to control. However, application of $75 \%$ RDF+ Azotobacter + VAM + vermicompost $\left(\mathrm{T}_{15}\right)$ produced maximum flower diameter (11.97 $\mathrm{cm})$. This may be due to Azotobacter which provides more amounts of nitrogen by fixing it through atmosphere. The positive effect of vermicompost on flower diameter has been reported in marigold by Mashaldi (2000) and Ajit Kumar (2002); Deshmukh et al., (2008) in gaillardia; Angadi (2010) and Verma et al., (2011) in chrysanthemum; Mukesh Kumar, (2015) in chrysanthemum while, VAM + Azotobacter + vermicompost $\left(\mathrm{T}_{2}\right)$ resulted in minimum flower diameter $(7.23 \mathrm{~cm})$. Fresh $(57.90 \mathrm{~g})$ and dry weight $(15.97 \mathrm{~g})$ of cut flower was greater in cv. Prof. Harris in comparison to cv. Sunil. Application of $75 \%$ $\mathrm{RDF}+$ Azotobacter + VAM + vermicompost $\left(\mathrm{T}_{15}\right)$ recorded maximum fresh $(60.91 \mathrm{~g})$ and dry weight (17.44 g) of cut flower. This increase in dry weight may be ascribed due to effects of plant growth regulators, high rate of photosynthates from vegetative parts to the reproductive parts, which subsequently might have resulted in higher fresh weight and dry matter accumulation. These findings are in line with the results reported in marigold by Mukesh Kumar et al., (2006), Sudhir et al.,
(2009) in chrysanthemum and Chaitra and Patil (2007) in China aster. While, minimum fresh $(52.37 \mathrm{~g})$ and dry weight $(12.87 \mathrm{~g})$ was recorded with application of VAM + Azotobacter + vermicompost $\left(\mathrm{T}_{2}\right)$.

The quality of cut stems depends on the various post harvest parameters. In the experiment, among the various treatments, water uptake $(90.78 \mathrm{ml})$ and vase life (20.41days) was recoded maximum in cv. Sunil as compared to cv. Prof. Harris. Application of $75 \% \mathrm{~N}$ and $\mathrm{P}+$ Azotobacter + $\mathrm{VAM}+$ full dose of $\mathrm{K}$ proved $\left(\mathrm{T}_{13}\right)$ to be most effective in improving the vase life of flowers (22.70 days). Water uptake was also recorded to be highest $(93.51 \mathrm{ml})$ under this treatment Similar beneficial effects on vase life have been also reported by Mahadik et al., (2017) in chrysanthemum, Moghal et al., (2006) in China aster, Parmar (2006) in rose and Dalve et al., (2008) in gladiolus; Mukesh Kumar (2015) in chrysanthemum whereas, lowest water uptake $(86.29 \mathrm{ml})$ and vase life (16.27 days) was found in treatment combination of $\mathrm{VAM}+$ Azotobacter + vermicompost $\left(\mathrm{T}_{2}\right)$.

As far as, effect of integrated use of chemical fertilizers, biofertlizers and vermicompost on soil nutrient status is concerned, the integrated nutrient management resulted in improved soil nutrient status. Pooled data of both the years reveals that irrespective of the effect of treatments available nitrogen content in the soil was recorded highest $(178.17 \mathrm{~kg} / \mathrm{ha})$ in $\mathrm{cv}$. Prof. Harris while, lowest (176.83 kg/ha) nitrogen content was recorded in cv. Sunil. Among treatments, application of $75 \% \mathrm{RDF}+$ Azotobacter + VAM + vermicompost (T 15) resulted in maximum $(184.23 \mathrm{~kg} / \mathrm{ha})$ nitrogen content in the soil followed by T 13 (183.43 kg/ha), T 3 (182.54 kg/ha), T 9 (182.32 kg/ha) and T5 (179.90 kg/ha). Whereas, minimum (169.09 kg/ha) available nitrogen content was recorded under T2 (VAM + Azotobacter + vermicompost). 
Table.1 Effect of integrated nutrient management on flowering and post-harvest attributes of chrysanthemum (pooled over two years)

\begin{tabular}{|c|c|c|c|c|c|c|c|c|c|}
\hline Treatment & $\begin{array}{l}\text { Flower } \\
\text { stem } \\
\text { length } \\
(\mathrm{cm})\end{array}$ & $\begin{array}{l}\text { Flower } \\
\text { diameter } \\
(\mathrm{cm})\end{array}$ & $\begin{array}{l}\text { Fresh } \\
\text { weight of } \\
\text { cut flower } \\
\text { (g) }\end{array}$ & $\begin{array}{l}\text { Dry weight } \\
\text { of cut } \\
\text { flower } \\
\text { (g) }\end{array}$ & $\begin{array}{c}\text { Water } \\
\text { uptake by } \\
\text { cut flower } \\
(\mathrm{ml})\end{array}$ & $\begin{array}{c}\text { Vase life } \\
\text { (days) }\end{array}$ & $\begin{array}{l}\text { Available } \\
\text { Nitrogen } \\
\text { (kg/ha) }\end{array}$ & $\begin{array}{c}\text { Available } \\
\text { Phosphorus } \\
\text { (kg/ha) }\end{array}$ & $\begin{array}{l}\text { Available } \\
\text { Potassium } \\
\text { (kg/ha) }\end{array}$ \\
\hline \multicolumn{10}{|c|}{ Cultivars } \\
\hline Prof. Harris & 37.98 & 10.00 & 57.90 & 15.97 & 88.92 & 17.83 & 178.17 & 23.72 & 187.72 \\
\hline Sunil & 48.66 & 9.44 & 55.64 & 15.06 & 90.78 & 20.41 & 176.83 & 23.48 & 188.92 \\
\hline$\overline{T_{1}}$ & 46.36 & 10.18 & 57.60 & 15.85 & 90.41 & 19.68 & 176.26 & 23.86 & 189.20 \\
\hline$\overline{T_{2}}$ & 36.04 & 7.23 & 52.37 & 12.87 & 86.29 & 16.27 & 169.09 & 17.01 & 177.73 \\
\hline $\mathbf{T}_{3}$ & 46.08 & 10.63 & 58.59 & 16.66 & 90.85 & 20.49 & 182.54 & 23.55 & 189.76 \\
\hline $\mathbf{T}_{4}$ & 38.17 & 8.30 & 54.96 & 14.64 & 88.16 & 17.50 & 174.75 & 21.52 & 187.56 \\
\hline$T_{5}$ & 49.96 & 11.14 & 59.17 & 16.97 & 91.75 & 21.47 & 179.90 & 26.08 & 191.15 \\
\hline$T_{9}$ & 44.19 & 10.43 & 57.72 & 16.06 & 90.33 & 19.80 & 182.32 & 25.46 & 189.70 \\
\hline $\mathbf{T}_{10}$ & 36.80 & 8.18 & 54.79 & 14.26 & 88.15 & 17.22 & 173.94 & 20.29 & 185.42 \\
\hline$T_{11}$ & 48.49 & 11.44 & 58.82 & 16.82 & 91.60 & 20.83 & 177.08 & 26.56 & 190.66 \\
\hline$T_{12}$ & 38.75 & 9.59 & 55.29 & 14.83 & 88.99 & 17.70 & 173.23 & 23.51 & 186.71 \\
\hline$T_{13}$ & 51.23 & 10.73 & 59.77 & 17.15 & 93.51 & 22.70 & 183.43 & 27.52 & 191.62 \\
\hline$T_{14}$ & 39.91 & 8.87 & 55.62 & 14.76 & 88.70 & 17.95 & 177.50 & 22.69 & 188.03 \\
\hline $\mathbf{T}_{15}$ & 53.68 & 11.97 & 60.91 & 17.44 & 92.80 & 21.52 & 184.23 & 28.53 & 192.26 \\
\hline $\mathbf{T}_{16}$ & 42.08 & 9.79 & 56.22 & 15.49 & 89.40 & 19.68 & 178.35 & 23.17 & 188.69 \\
\hline C.D. at $5 \%$ & 0.424 & 0.339 & 0.489 & 0.419 & 0.333 & 0.359 & 0.366 & 0.895 & 0.224 \\
\hline
\end{tabular}


Higher availability of nitrogen in soil with the treatment of biofertilizers in combination with vermicompost and chemical fertilizer can be attributed to direct application of chemical fertilizer and release of nitrogen through vermicompost and biological fixation of atmospheric nitrogen by bacterial fertilizers. Vermicompost is a better source of nitrogen and a good carrier material for Azotobacter (Ismail, 1995) and vermicompost brought up the population of Azotobacter, which might have resulted in higher available nitrogen in the soil.

Pooled data of both the years reveals that the maximum mean available phosphorus content $(23.72 \mathrm{~kg} / \mathrm{ha})$ in the soil was exhibited by $\mathrm{cv}$. Prof. Harris, whereas available phosphorus content in the soil was found to be minimum $(23.48 \mathrm{~kg} / \mathrm{ha})$ in cv. Sunil. Among treatments, highest mean available phosphorus content $(28.53 \mathrm{~kg} / \mathrm{ha})$ in the soil was obtained in T15 $(75 \%$ RDF+ Azotobacter+ VAM + vermicompost) followed by T13 (27.52 kg/ha), T11 (26.56 kg/ha), T5 (26.08 kg/ha) and T9 (25.46 kg/ha). Whereas, lowest (17.01 $\mathrm{kg} / \mathrm{ha}$ ) mean available phosphorus content was recorded under T2 (VAM + Azotobacter + vermicompost).

Pooled data of both the years reveals that irrespective of the effect of treatments mean available potassium content in the soil was recorded highest $(188.92 \mathrm{~kg} / \mathrm{ha})$ in $\mathrm{cv}$. Sunil while, lowest (187.72 kg/ha) mean potassium content was recorded in cv. Prof. Harris. Among treatments, application of $75 \% \mathrm{RDF}+$ Azotobacter + VAM + vermicompost (T15) resulted in maximum $(192.26 \mathrm{~kg} / \mathrm{ha})$ mean potassium content in the soil followed by T13 (191.62 kg/ha), T5 (191.15 kg/ha), T11 (190.66 kg/ha) and T7 (190.22 kg/ha). Whereas, minimum (177.73 kg/ha) mean available potassium content was recorded under T2 (VAM + Azotobacter + vermicompost).
The available phosphorus and potassium content were highest in the treatments with VAM, vermicompost and chemical fertilizers in soil. The build-up of available phosphorus and potassium in the soil could be attributed to the organic acids which were released during microbial decomposition of vermicompost increasing the available phosphorus and potassium in soil (Khan et al., 1994). Application of chemical fertilizer also enhanced the nutrient availability in soil but at lower amount as compared to combined use of nutrients from different sources. The lower values of available NPK in soil can be due to maximum utilization of applied nutrients by the crop, which were in the most available form. Reddy and Reddy (1998) also reported that available NPK content was increased by organic manure in combination with the chemical fertilizers.

Thus, the results have proved that application of 75 per cent NPK from chemical fertilizer along with biofertilizers (Azotobacter and VAM) and vermicompost is most effective in enhancing the flowering attributes of chrysanthemum and soil nutrient status as compared to mere application of recommended dose of fertilizers or organic fertilizers. This indicates the possibility of reducing the dose of chemical fertilizers, which is cost effective and eco-friendly for the cultivation of chrysanthemum on sustainable basis. So, it can be concluded that by reducing the levels of chemical fertilizers and optimizing the dose of different organic fertilizers, yield and quality can be improved in ornamental crops without adversely affecting the edaphic and environmental features.

\section{References}

Ajit Kumar. 2002. Effect of organic and inorganic fertilizers on growth, yield and post-harvest life of marigold. M. 
Sc. (Agri.) Thesis, Univ. Agric. Sci., Dharwad (India).

Angadi, A. P. 2010. Integrated nutrient management studies on growth, yield and quality of garland chrysanthemum (Chrysanthemum coronarium L.). M. Sc. (Horti.) Thesis, Univ. Agric. Sci., Dharwad (India).

Dalve, N. V, Rangwala, A. D. and Joshi, G. D. 2008. Effect of spacing and graded levels of fertilizers on yield attributes of gladiolus. J. Maharashtra Agric. Univ. 33 (2): 167-170.

Das, D., Dwivedi, B.S. and Meena, M.C. 2015. Integrated Nutrient Management for Improving Soil Health and Crop Productivity. Indian J. Fert., 11(4): 6483.

Deshmukh, P. G., Khiratkar, S. D., Badge, S. A. and Bhongle, S. A. 2008. Effect of bioinoculants with graded dose of NPK on growth and yield of gaillardia. $J$. Soils and Crops. 18 (1): 212-216.

Ismail, S. 1995. Earth worms in soil fertility management in organic agriculture. Thampan, P.K. (ed.), Peekay Tree Crops Development Foundation, Cochin, pp. 78-95.

Khan, G., Gupta, S.K. and Banarg, S.K. 1994. Studies on the solubilization of phosphorus in presence of different city wastes. Journal of Indian Society of Soil Science, 29:123-124.

Mahadik, M.K., Dalal, S.R., Disha, A. P. and Wararkar, S.M. 2017. Nutritional and economic studies in chrysanthemum cv. PDKV Ragini. Journal of Pharmacognosy and Phytochemistry. 6(5): 2646-2650.

Mashaldi, A. 2000. Effect of organic and inorganic fertilizers on growth, yield and post-harvest life of marigold (Tagetes erecta L.) cv. Double Orange. M. Sc. (Agri.) Thesis Univ. Agric. Sci., Bangalore (India).
Moghal, S. A., Khiratkar, S. D., Chopde, N. K., Dalvi, A. M., Kuchanwar, O. D. and Khobragade, Y. R. 2006. Effect of organic manures and biofertilizers with reduced doses of nitrogen on growth, yield and quality of China aster. J. Soils and Crops. 16 (1): 180-185.

Mukesh Kumar, Sultan Singh, Sharma, S. K., Dahiya, D. S. and Beniwal, L. S. 2006. Effect of biofertilizer on growth and flowering of marigold cv. Pusa Narangi. Haryana J. Hort. Sci. 35 (1\&2): 71-72.

Mukesh Kumar. 2015. Impact of different sources of nutrients on growth and flowering in chrysanthemum (Chrysanthemum morifolium Ramat.) cv. Yellow Gold. $J$ of Plant Development Sci. 7 (1): 49-53.

Nalawadi, U. G. 1982. Nutritional studies in some varieties of marigold (Tagetes erecta L.). Ph.D. Thesis, Univ. Agric. Sci., Bangalore (India).

Nandre, D. R., Jogdande, N. D., Dalal, S. R., Bansode, A. B. and Chaudhale, B. S. 2005. Effect of Azotobacter on growth and yield on China aster under reduced nitrogen levels. Advances in Plant Sci. 18(1): 87-89.

Parmar, K. D. 2006. Integrated nutrient management in rose cv. Gladiator. M.Sc. (Horti.) Thesis, Junagarh Agricultural University, Junagadh (India).

Reddy, G.B. and Reddy, M.S. 1998. Effect of organic manures and nitrogen levels on soil available nutrients in maize soyabean cropping system. Journal of Indian Society of Soil Science, 46(3): 474-476.

Sudhir Chandra, Nidhi Srivastava, Raghvendra, P. Narayan, Nidhi Sharma and Kehri H. K. 2009. Efficiency of microbial inoculatants on reducing the phosphatic fertilizers input in chrysanthemum. Indian J. Hort. 66 (1): 83-87. 
Sunitha HM, Hunje R. 2010. Effect of plant population and integrated nutrient management on growth, seed yield and quality of African marigold (Tagetes erecta L.). Karnataka J Agric. Sci. 23(5):783-786.

Verma, S. K., Angadi, S. G., Patil, V. S., Mokashi, A. N., Mathad, J. C. and Mummigatti, U. V. 2011. Growth, yield and quality of chrysanthemum (Chrysanthemum morifolium Ramat.) cv. Raja as influenced by integrated nutrient management. Karnataka $J$. Agril. Sci. 24 (5): 681-683.

Wani, M.A., Wani, S.A., Ahmad, M.S., Lone, R.A., Gani, G., Khan, F.U. and Nelofar. 2017. Integrated Nutrient Management (INM) Approaches in Flower Crops. International Journal of Current Microbiology and Applied Sciences 6 (3): 254-265.

\section{How to cite this article:}

Geeta Pandey, Rakesh Kumar, Santosh Kumar and Ajit Kumar. 2018. Effect of Integrated Nutrient Management on Floral Parameters and Soil Nutrient Status in Chrysanthemum (Chrysanthemum morifolium Ramat.). Int.J.Curr.Microbiol.App.Sci. 7(05): 1984-1990. doi: https://doi.org/10.20546/ijcmas.2018.705.233 